\title{
Determinants of Management Accounting Information Systems Quality on Management Accounting Information Quality
}

\author{
YanuarRamadhan \\ Departement Economics and Business \\ Universitas Esa Unggul \\ Jakarta, Indonesia \\ yanuar.ramadhan@esaunggul.ac.id
}

\begin{abstract}
This study aims to investigate and analyze the quality of management accounting information system on the quality of management accounting information. The phenomenon that occurs in several companies in Indonesia shows that information system of management accounting at the company has not yet qualified or have good quality so it gives the impact on quality of management accounting information. The data used in this study were obtained through questionnaires survey by distributing to 30 companies manufacturing consumer goods industry sectors listed on the Indonesia Stock Exchange. Testing data using Linear Simple Regression. The research used explanatory method. The results showed that the quality of management accounting information systems affect the quality of management accounting information. With a quality management accounting information systems, top management can be helped in making the right decisions by getting relevant, accurate, complete, timeliness, scope and aggregation information.
\end{abstract}

Keywords-quality of management, formatting, accounting information systems, quality of management accounting information

\section{INTRODUCTION}

Information can be define as data that is processed into a form that is more useful and meaningful for those who receive [1] and Baltzan (2014) said "information is the data converted into a meaningful and useful context" [2].

According to O'Brien and Maracas (2010) "is information product that the characteristics, attributes or quality will help the user to get valuable information" [3]. The opinion also stated by Gelinas et al. (2012) that "accounting information with good quality are useful to assist users in making beneficial decisions" [4]. The quality of information pertains to the quality of the output resulted by the information system [5].

Some phenomenonsrelated to management accounting information system that is not qualified due to its bad quality as submitted by Fuad Rahmany, Director General of Taxation (2014), which considered that one of the weaknesses that must be addressed is the process of tax collection that is not integrated data collection system of all lines yet [6]. Also, the case of PT Great River disclosed by Bapepam, in which the information presented is not a reliable or inaccurate due to the overstatement of the recording of the presentation and sales accounts receivable [7].

Chitmun and Ussahawanitchakit (2011) with the result that "the timeliness management accounting system has a significant positive effect on information quality, integration of management accounting system has a positive impact on information quality" [8].

Based on the phenomenon described, the authors are interested doing a research to find out how much the influence of the Quality of the Management Accounting Information Systems to Management Accounting Information Quality. The aim of the present research is to measure the impact of Quality of Management Accounting Information Systems on the Quality of Management Accounting Information.

\section{LITERATURE REVIEW}

\section{A. Quality Of Management AccountingInformation System}

As for the related dimension, the opinions and statements stated, it can be concluded that the dimensions of Quality of Management Accounting Information System are Integration, Flexibility, Accessibility, Formalization, Media richness. Further indicators of each dimension of quality is a management accounting information system integration, consisted of: (a) The integration between the system components (Heidmann, 2008: 87 [9], Azhar Susanto, 2013: 73-83) [10], (b) Integration between the sub-components of the system (Azhar Susanto, 2013: 73-83). Flexibility is composed of: (a) Ability to customize the user's needs 
(Heidmann, 2008: 88), (b) Ability to adapt to environmental changes (Heidmann, 2008: 88). Accessibility consists of: (a) Easily accessible (Heidmann, 2008: 89, Stair \& Reynolds, 2012: 32) [11], (b) accessible with the development of information technology (Heidmann, 2008: 89, Stair \& Reynolds, 2012: 32). Formalization: Follow the rules and regulations (Heidmann, 2008: 90). Media richness consist of: (a) Using many channels that facilitate communication (Heidmann, 2008: 90), (b) Facilitating the interaction between parts (Heidmann, 2008: 90).

a. Management Accounting Information Quality

In this study, based on the explanations that have been described before, the dimensions and indicators that can be used for each component of the quality of management accounting information are as follows: a). Relevance, there is suitable information based on the needs (Hall, 2011:13 [12]; McLeod, 2008:43 [13]), having capability of producing the appropriate decisions or actions (Hall, 2011:13), b). Accuracy, information generated reflect the real situation (McLeod, 2008:43), c). Completeness, the information provided must be complete, as needed (McLeod, 2008:43), the information provided in accordance with the provisions so that it can be understood / interpreted (Heidmann, 2008: 85), d). Timeliness, information that available at the time the information is needed (McLeod, 2008:43; Chenhall and Morris, 1985:17 [14]), information presented in accordance frequency defined reports (Heidmann, 2008: 85), e). Scope, includes information from internal and external (Heidmann, 2008:46; Gul and Chia, 1994:415 [15]), including financial and non-financial information (Heidmann, 2008:46; Bowens and Abernethy, 2000:223 [16]; Chenhall and Morris, 1985:17), including information that is both quantitative and qualitative (Heidmann, 2008:46), which includes information on preliminary data / ago and can estimate the occurrence of future (historical/future oriented) (Heidmann, 2008:46; Chenhall and Morris, 1985:17), f). Aggregation, Information delivered concise yet complete (Chenhall and Morris, 1985:17).

\section{b. $\quad$ Framework \\ $i$. The Influenceof Management Accounting Information Systems Quality On Information Quality of Management Accounting}

Hall (2011: 7) says that: "Information system is the set of formal procedures by the which the data are collected, processed into information, and distributed to users". Hansen and Mowen (2012:4) [17]: "The system of management accounting information is not bound by any formal criteria that define the nature of the process, input, or output". The opinion of management accounting information system revealed by Bagranoff (2010:5) [18], which revealed that "An management accounting information system (MAIS) is a collection of the data and processing procedures that creates the needed information for its users". As Atkinson et. al. (2012: 5,6) states that the "developed system should produce accurate information with considering consequences of the costs and benefits" [19]. Moreover, Xu (2003:ii) states that "management accounting information system affects the quality of the information" [20]. As well as the opinions expressed by Heidmann (2008:45) and Boockholdt (1999:3) argues that: "management accounting information systems provided only internal, historical, and financial information. Over time, they evolved to include a broader scope of information, including external, future-oriented, qualitative and non-financial information" [21].

The results of the Shoommuangpak (2011) says that "The influence of effectiveness of implementation is management accounting systems provide management with sound advice about accounting information roomates affect decision making" [22]. Further Laudon and Laudon (2014:485) states that "Currently under any level employee responsible for some of the things in this decision, with the information system makes the information available to lower levels within the company" [23]. Heidmann (2008:45) also explain more specifically that "management accounting information systems process the data and provide the result as management accounting information to managers".

Here is a picture framework as a basis to propose a hypothesis which is based on the framework above, is as follows:

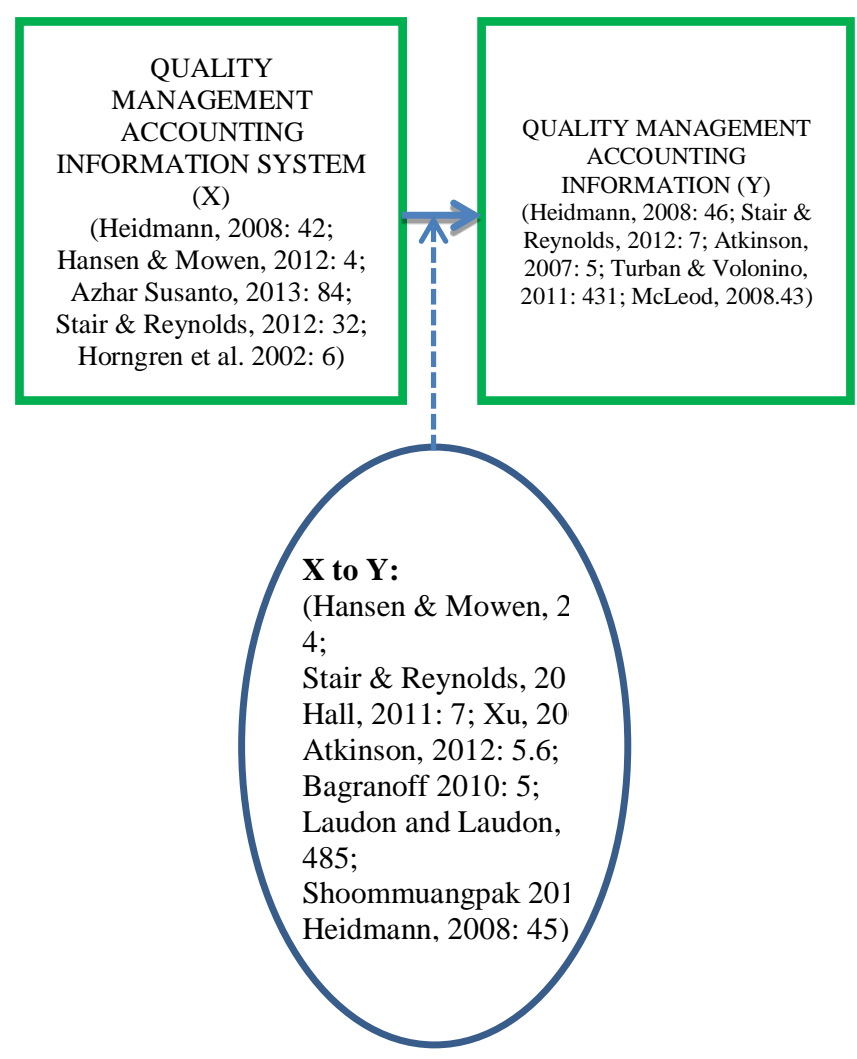

Fig. 1. Framework 


\subsection{Hypothesis}

Based on the framework, the hypothesis proposed in this study is the quality of management accounting information system affects the quality of management accounting information.

\section{RESEARCH METHODOLOGY}

\section{A. Object of Research}

According to Cooper (2014:248), object is the concepts of ordinary experience [24]. In addition, Kothari (2004:69) states "measure of physical objects as well as abstract concepts. By measurement we mean the process of assigning numbers to objects or observations, the level of measurement being a function of the rules under roomates the numbers are assigned" [25]. The object of this research is the quality of management accounting information systems and the quality of management accounting information.

\section{B. Research Methods}

In this research used is descriptive and explanatory research. Researchers want to get answers and expected to describe the characteristics of the phenomenon of variables related to the problem and practice about management accounting information systems and management accounting information. This study is expected to explain how big the influence or importance of management accounting information system quality on the quality of management accounting information.

\section{Operationalization Variable}

Based on the elaboration, it is required the identification of variables used in this study in order to obtain the data and do statistical analysis, is as follows:

\section{1) Quality of Management Accounting Information System}

Management accounting information system is an information system that produces output by using input and through various processes required with the result that can meet the needs of management in decision making to achieve organizational goals. It is based on the synthesis of theory and research, among others from 1). Hansen \& Mowen, 2012: 4; 2). Stair \& Reynolds, 2012: 32; 3). Rom, 2008: 28 [26]; 4). Horngren et al., 2002: 6 [27]; 5). Weber, 1999: 895 [28]; 6). Heidmann, 2008: 87-90; 7). Azhar Susanto, 2013: 73-83; 8). Atkinson et al., 2012: 2; 9). Bouwens and Abernethy, 2000: 223; 10). Petter et al., 2008: 239 [29]; 11). DeLone\& McLane, 2003:13.

Based on the elaboration, the variable of Management Accounting Information Systems Quality can be represented by the notation $\mathrm{X}$. Then the following description will be described briefly about the dimensions and indicators that can be used for each component of the quality of management accounting information system are as follows: a) Integration, consists of:

1. The integration between component system/linked data between parts with the same function (Heidmann, 2008: 87; Azhar Susanto, 2013: 73-83).

2. The integration between the subcomponentsystem/linked data between parts with different functions (Heidmann, 2008: 87; Azhar Susanto, 2013: 73-83).

b) Flexibility, consists of:

1. Able to adjust to the user's needs (Heidmann, 2008: 88; DeLone \& McLane, 2003: 13).

2. Able to adapt to changing circumstances (situation and condition) (Heidmann, 2008: 88; DeLone \& McLane, 2003: 13).

c) Accessibility, consists of:

1. Easily accessible (Heidmann, 2008: 89; Stair \& Reynolds, 2012: 32)

2. Can be accessed with the development of information technology (Heidmann, 2008: 89; Stair \& Reynolds, 2012: 32)

d) Formalization: Follow the rules and regulations exist (Heidmann, 2008: 90).

e) Media richness consists of:

1. Frequently use various channels that makes communication easier (Heidmann, 2008: 90).

2. Facilitate interaction between parts (Heidmann, 2008: 90).

\section{2) Management Accounting Information Quality}

The quality of management accounting information consist offinancial information/non-financial, internal/ external, qualitative/quantitative derived from a process that has a meaning and in accordance with the needs of management in support of decision-making. It is based on the synthesis of theory and research, among others of 1) Atkinson et al., 2012: 34; 2) Laudon and Laudon, 2014: 490; 3) Turban \&Volonino, 2011: 431 [30]; 4) McLeod \& Schell, 2008: 43; 5) Mejia et al., 2005: 732 [31]; 6) O'Brien \& Maracas, 2010: 350; 7) Wilkinson, 2000: 18; 8) Hall, 2011: 13; 9) Hargis et al., 2004: 15-16; 10) Stair \& Reynolds, 2012: 7; 11) Romney \&Steinbart, 2012: 25 [32]; 12) Weber, 1999: 897; 13) Heidmann, 2008: 46; 14) Azhar Susanto, 2013: 37; 15) Chenhall and Morris, 1986: 19; 16) Gul and Chia, 1994: 143.

Based on the elaboration, the Management Accounting Information Quality variables can be represented with the following notation Y. Further description will be described briefly about the dimensions and indicators that can be used for each component of the quality of management accounting information act as follows:

\section{a) Relevance}

1. There is match information produced and needed (Hall, 2011: 13; McLeod, 2008: 43)

2. Able to produce the right decisions or actions (Hall, 2011: 13; Laudon and Laudon, 2014: 490)

b) Accuracy, Information generated reflect the real situation (McLeod, 2008: 43)

c) Completeness 
1. The information provided must be complete, as needed (McLeod, 2008: 43)

2. The information provided by the provisions so it can be interpreted (Heidmann, 2008: 85)

\section{d) Timeliness}

1. Information is available or existed when it is needed (McLeod, 2008: 43; Chenhall and Morris, 1986)

2. The information presented under the specified reporting frequency (Heidmann, 2008: 85)

e) Scope (Heidmann, 2008: 82)

1. Includes the information from internal and external of a company (Heidmann, 2008: 46; Gul and Chia, 1994: 143)

2. Includes financial and non-financial information (Heidmann, 2008: 46; Bowens and Abernethy, 2000: 223; Chenhall and Morris, 1985: 17)

3. Information includes quantitative and qualitative (Heidmann, 2008: 46)

4. Includes current and past data, and estimate future events (historical / future oriented) (Heidmann, 2008: 46; Chenhall and Morris, 1985: 17)

f) Aggregation(Chenhall and Morris, 1986). Information delivered concise yet complete.

\section{Population and Sample Research}

Based on data from the Indonesia Stock Exchange, there were 40 companies that considered into consumer goods industry category which is the target population and will be the object of research. This is the type of business that is currently growing very rapidly and become one of the sector / industry which has enormous influence on the economy or the growth rate of Indonesia. It can be seen from the strengthening or the composite stock price index growth in which the consumer goods industry sector is the sector most high-growth industry.

To test the hypothesis of this study, researchers used a simple linear regression method with the objective to identify and explain how big the influence the level of significance of the independent variables (quality of management accounting information system) while influencing dependent variable (quality of management accounting information).

\section{E. Sources And Methods of Data Collection}

\section{Data Source}

The primary data used in this study were collected by researchers through a list of questionnaire addressed to the respondents in order to obtain the facts and factual information from respondents.

\section{Method of Collecting Data}

The method used in this research is by using questionnaires, provide direct questionnaire or by e-mail.

\section{Data Testing Methods}

The measuring instrument used is not valid and can't be trusted, then the research results will not reflect the real condition, to test the sincerity of respondents, it needed two kinds of test which are: a test of validity and test of reliability.

After the test of validity and test of reliability, then the classic assumption test including normality test, heteroscedasticity test, multicoloniarity test, and autocorrelation test. Test is done through data analysis using simple linear regression.

\section{F. Draft Analysis And Testing Hypotheses}

\section{Draft Analysis}

Data analysis is done through descriptive analysis to describe the variable characteristics in order to support problem solving to obtain advice operationally.

\section{Hypothesis Testing}

To determine whether the regression coefficient is significant or not, test the hypothesis by comparing the value of significance (Sig.) With a probability of 0.05 or by comparing the value of $t$ arithmetic with $t$ table. Basis for a decision is if $\mathrm{t}>\mathrm{t}$ table, it has a significant influence. Meanwhile, if $\mathrm{t}<\mathrm{t}$ table, it does not have significant influence. Or if Sig. $>$ A (0.05), the regression coefficient is not significant. Whereas if Sig. $<\mathrm{A}(0.05)$, the regression coefficient is significant.

\section{RESUlTS ANALYSIS}

Here are the results of the analysis of the data obtained in the field. This study uses simple regression analysiswith variable of Management Accounting Information System Quality and Management Accounting Information Quality, which was distributed to 65 respondents

\section{A. Descriptive Analysis}

The average score responder unit on the Quality of Management Accounting Information System are between 2.8 and 4.4. This category categorized up to the high/good. The average score respondent unit to Management Accounting Information Quality are between 3.2 and 4.3. This category categorized up to the high / good.

\section{B. Simple Regression Analysis}

Simple regression is used to find the influence of independent variables on the dependent variable directly. Before the simple regression analysis, classical assumption is done in order to get equality between good and not biased equation.

\section{Classic Assumption Test}

Classic assumption test used is the test of normality and heteroscedasticity test as follows:

a) Normality Test

To detect regression model with normal distribution or not, Kolmogorov-Smirnov test was used, with data 
required had normal distribution if the sig is above 0.05 . Results of tests of normality, Sig value is above 0.05 , so it can be said that the regression model is normal

b) Heteroscedasticity Test

To prove whether heteroscedasticity, variable correlate with the absolute value of residual using Spearman rank correlation. From the output shows no significant correlation. It is seen from the p-value ( $\mathrm{Sig}$ ) greater than 0.05 . It can be concluded not occur heteroscedasticity in regression models.

\section{Simple Linear Regression Analysis}

Multiple analysis methods used to observe the effect of Management Accounting Information Systems Quality (X) to the Quality of Management Accounting Information (Y) used the simple linear regression analysis with the following equation:

$$
Y=a+b 1 x l
$$

Where:

$\mathrm{Y}=$ Quality of Management Accounting Information

$\mathrm{X}=$ Quality of Management Accounting Information Systems

$a \quad=$ constant

\section{$b 1, b 2,=$ Regression Coefficients}

Table I explained about the influence of Management Accounting Information System Quality (X) on Management Accounting Information Quality (Y) using simple regression analysis. Results of statistical processing for simple regression analysis are presented in the following table:

TABLE I. SIMPLE REGRESSION ANALYSIS

\begin{tabular}{|c|c|c|}
\hline Variables & Regression Coefficients & Std. Error \\
\hline (Constant) & 0.168 & 0.259 \\
\hline $\mathrm{X} 1$ & 0.743 & 0.078 \\
\hline
\end{tabular}

Source: Primary Data Processing, 2018

Based on calculations in the table above, obtained by a simple linear regression equation is as follows:

$$
\mathrm{Y}=0,168+0.743 \mathrm{X} 1
$$

If the regression coefficients describe the independent variables predicted constant or equal to zero, then the value of the dependent variable of 0.168 . The regression coefficient for the independent variable is positive, indicating a direct relationship between Quality of Management Accounting Information Systems (X) with the Management Accounting Information Quality (Y). X variable regression coefficient of 0.743 implies for each increment of Management Accounting Information Systems Quality (X) of the unit will lead to increased quality of Management Accounting Information (Y) of 0.743.

\section{i. Correlation Analysis}

To determine the relationship between Quality of Management Accounting Information System with Management Accounting Information Quality, Pearson correlation analysis was used. Based on the results of statistical software output, it was obtained correlation coefficient $(\mathrm{R})$ of 0,781 . This shows that there is a strong relationship between Quality of Management Accounting Information System (X) and ManagementAccounting Information Quality (Y).

\section{Coefficient Of Determination}

The big of the effect of Management Accounting Information System Quality (X) on the Quality of Management Accounting Information (Y) is $\mathrm{R}^{2}$ of $60.9 \%$ indicates that $60.9 \%$ of the variation in Management Accounting Information Quality (Y) can be explained by the variable quality of Management Accounting Information Systems (X). While the rest of $39.1 \%$ can be explained by other variables besides Quality of Management Accounting Information Systems (X).

\section{Hypothesist Test}

$\mathrm{H} 0$ : There is no significant effect of Management Accounting Information System Quality on Management Accounting Information Quality.

H1 : There is a significant influence of Management Accounting Information System Quality on Management Accounting Information Quality.

Analysis of the effect of variable Management Accounting Information Systems Quality (X) on Management Accounting Information Quality (Y) obtained results based on statistical software output.

Tabel 2 explained about analysis of the effect of variable Management Accounting Information Systems Quality (X) on Management Accounting Information Quality (Y) obtained results based on statistical software output.

TABLE II. REGRESSION ANALYSIS OF MANAGEMENT ACCOUNTING INFORMATION SYSTEM QUALITY ON INFORMATION QUALITY OF MANAGEMENT ACCOUNTING

\begin{tabular}{|c|c|c|c|c|c|c|c|}
\hline Variables & $\begin{array}{c}\text { Regression } \\
\text { Coefficients }\end{array}$ & $\mathbf{t}$ & $\mathbf{d f}$ & $\mathbf{t}$ table & Sig & Information & Conclusion \\
\hline $\mathrm{X} 1$ & 0.743 & 9.510 & 58 & 2,002 & 0,000 & Ho rejected & Significant \\
\hline
\end{tabular}

Source: Primary Data Processing, 2018

Depend on conditions described earlier, which obtained $\mathrm{t}$-count equal to 9.510 and the degrees of freedom (nk-1) or obtained figures $60-1-1=58 \mathrm{t}$ table 2.002 , so $\mathrm{t}$ count $>\mathrm{t}-$ table. That means, $\mathrm{H} 0$ rejected and $\mathrm{H} 1$ accepted, then there is a significant influence between Management Accounting Information System Quality on Management Accounting Information Quality.

\section{CONCLUSION}

The research can be achieved that the management accounting information system quality affects the management accounting informationquality. 


\section{REFERENCES}

[1] Mardi. 2011. Sistem Informasi Akuntansi. Ghalia Indonesia.

[2] Baltzan, P. 2014. Business Driven Information Systems, Fourth Edition. McGraw-Hill / Irwin.

[3] O'Brien, JA, and Marakas G, M. 2010. Introduction to Information Systems. Fifteenth Edition. The McGraw-Hill Companies, Inc.

[4] Gelinas, UJ., and Dull, RB.2008. Accounting Information Systems, 7th Edition. Thomson SouthWestern.

[5] DeLone, WH and McLean, ER, 1992. Information Systems Research.Volume 3, No. 1. Information Systems Success: The Quest for the Dependent Variable, p. 60-95

[6] Fuad Rahmany. 2014. Ditjen Pajak Harus Dipisah. Melalui https://issuu.com/hariannasional/docs/ 28nov2014th02no436

[7] Fuad Rahmany. 2006. Bapepam: Akuntan dan Great River Terlibat Konspirasi. Melalui http://tempo.co.id/hg/ekbis/2006/12/08/brk,200612 08-89121, id.html. 08 Desember 2006

[8] Chitmun, S. and Ussahawanitchakit, P. 2011. Management Accounting Decision Making Systems Sophistication and Performance. Journal of Academy of Business and Economics. 2011, Volume 11 Number 3

[9] Heidmann, M. and Schaffer, U. 2008. The Role of Management Accounting Systems in Strategic sensemaking. Research in Management Accounting and Control.Gabler 'EditionWissenschaft.

[10] Azhar Susanto. 2013, Sistem Informasi Akuntansi, Struktur-Pengendalian-Resiko-Pengembangan. Lingga Jaya. Bandung.

[11] Stair, RM and Reynolds, GW 2010. Principles of Information Systems. Ninth Edition. Course Technology, Cengage Learning.

[12] Hall, JA. 2011. Accounting Information Systems, 7th Edition, South-Western, Cengage Learning.

[13] McLeod, R.Jr. and Schell, GP. 2008. Management Information Systems. Issue 10. Four Salemba.

[14] Chenhall, RH., And Morris, D. 1986. The Impact of Structure, Environment and Interdependence on the Perceived Usefulness of Management Accounting Systems. The Accounting Review, 61 (1): 16-35, p. 19
[15] Gul, FA. and Chia, YM. 1994. The Effect of Management Accounting Systems, Perceived Environmental Uncertainty and Decentralization on Managerial Performance. Accounting Organization and Society. Volume 19, No. 4, pp. 415

[16] Bouwens, J., and Abernethy, MA 2000. The consequences of customization on management accounting system design. Pergamon. Accounting, Organizations and Society. 25 (2000), p. 221-241

[17] Hansen, DR and Mowen, MM, 2012. Managerial Accounting, Issue 8. Salemba Four. Cengage Learning.

[18] Bagranoff, NA., Simkin, MG., And Norman, CS. 2010. Core concepts of: Accounting Information Systems. Eleventh Edition. John Wiley \& Sons, Inc.

[19] Atkinson, AA, Kaplan, RS, Matsumura, EM, and Young SM 2012. Management Accounting. Fifth edition. Volume 2. Publisher: Index.

[20] Xu, Hongjiang. 2003. Critical Success Factors for Accounting Information Systems Data Quality. University of Southern Queensland.

[21] Boockholdt, JL, 1999. Accounting Information System. Fifth Edition. McGraw Hill

[22] Shoommuangpak, P. 2011. Effectiveness of Management Accounting Implementation, Decision Making Quality and Performance: An Empirical Study of Thai-Listed Firms. International Journal of Business Strategy. Volume 11 Number 1.

[23] Laudon, KC, \& Laudon, JP. 2014. Management Information Systems (Managing the Digital Firm). Thirteenth Edition.

[24] Cooper, DR and Schindler, PS 2014. Business Research Methods, Twelfth edition. The McGrawHill Companies, Inc., 1221 Avenue of the Americas, New York, NY, 10020.

[25] Kothari, CR 2004. Research Methodology, Methods \& Techniques. Second revised edition. New Age International (P) Limited, Publishers.

[26] Rom, A. 2008. Management Accounting and Integrated Information Systems, How to exploit the potential for management accounting of information technology. Sumfundslitteratur Publishers, hlm. 28

[27] Horngren, CT, Sundem, GL, and Stratton, WO 2002.Introduction to Management Accounting.12th edition.Prentice Hall.

[28] Weber, R. 1999. Information Systems Control and Audit. Prentice Hall. 
[29] Petter S., DeLone W. and E. McLean Information Systems 2008. Measuring Success: Models, Dimensions, Measures, and interrelationships. European Journal of Information Systems 17, 236263.

[30] Turban, E. dan Volonino, L. 2011. Information Technology for Management -Improving Strategic and Operational Performance. 8th Edition. John Wiley \& Sons, Inc.

[31] Mejia, LRG, Balkin, DB, and Cardy, RL, 2005. Management. Second Edition, McGraw-Hill.

[32] Romney, MB and Steinbart, PJ2012. Accounting Information Systems, Global Edition. Twelfth Edition. Pearson Education Limited. 